DOI: $\underline{\text { https://doi.org/10.24127/ajpm.v9i4.3152 }}$

\title{
KEEFEKTIFAN INQUIRY DAN LEARNING CYCLE 7E DITINJAU DARI HASIL BELAJAR, KEMAMPUAN PENALARAN, DAN KETERAMPILAN KOLABORATIF
}

\author{
Yosepha Patricia Wua Laja ${ }^{*}$ \\ ${ }^{1}$ Pendidikan Matematika, Universitas Timor, Nusa Tenggara Timur, Indonesia \\ *Corresponding author. Jalan El Tari Km. 9 Kelurahan Sasi, Kefamenanu, Indonesia \\ E-mail: $\quad y o s e p h a l a j a @ u n i m o r . a c . i d^{1)}$
}

Received 12 October 2020; Received in revised form 12 December 2020; Accepted 21 December 2020

\begin{abstract}
Abstrak
Tujuan penelitian ini adalah untuk mendeskripsikan keefektifan inquiry dan learning cycle $7 e$ serta membandingkan keefektifan inquiry dan learning cycle $7 e$ ditinjau dari hasil belajar, kemampuan penalaran dan keterampilan kolaboratif peserta didik SMP pada materi peluang. Penelitian ini adalah penelitian eksperimen semu (Quasi Eksperimen). Subjek penelitian ini adalah seluruh peserta didik kelas VIII se-kota Kupang yang sekolahnya menerapkan kurikulum 2013 dan nilai ujian kenaikkan kelas di atas 70. Sampel penelitian ini adalah peserta didik SMPN 11 kota Kupang kelas VIII A yang berjumlah 31 siswa dan kelas VIII B berjumlah 29 siswa yang dipilih secara acak. Instrumen penelitian yang digunakan meliputi tes hasil belajar, tes kemampuan penalaran, dan lembar penilaian teman sejawat keterampilan kolaboratif yang telah divalidasi dan reliabel. Teknik analisis data yang digunakan adalah uji multivariate (MANOVA), kemudian dilanjutkan dengan uji Independent Sample $t$ Test. Taraf signifikansi untuk semua analisis adalah 5\%. Hasil penelitian menunjukkan bahwa inquiry dan learning cycle $7 e$ efektif ditinjau dari hasil belajar, kemampuan penalaran dan keterampilan kolaboratif; serta inquiry sama efektifnya dengan metode learning cycle 7e ditinjau dari hasil belajar, kemampuan penalaran namun lebih efektif ditinjau dari keterampilan kolaboratif.
\end{abstract}

Kata Kunci: Hasil belajar; Inquiry; kemampuan penalaran; keterampilan kolaboratif; learning cycle 7e

\begin{abstract}
The aim of the study was to describe the effectiveness of inquiry and learning cycle $7 e$ and as well as compare the effectiveness of inquiry and learning cycle 7e in terms of learning outcome, reasoning and collaborative skill of junior high school students on probability material. This was a quasi experimental quantitative study. The subject of the study was all eighth grade students in Kupang whose school applied Curriculum 2013 and the score of final test was above 70. The students of VIII A consisted of 31 students and VIII B consisted of 29 students of SMPN 11 Kota Kupang as the sample that was randomly selected.. The used instruments of the study were tests and non tests. The learning outcome and reasoning ability were measured using tests, while the collaborative skill was measured using peer assessment sheet, which has been validated and reliable. The data analysis technique used the multivariate test (MANOVA), followed by independent sample t-test. The significance level for all analyses was 5\%. The research result indicated that inquiry and learning cycle $7 e$ were effective in term of learning outcome, reasoning ability, collaborative skill; and inquiry was effective as learning cycle 7e in term of learning outcome, reasoning and proof ability but inquiry was more effective than learning cycle $7 e$ in term of collaborative skill.
\end{abstract}

Keywords: Collaborative skill; inquiry; learning cycle 7e; learning outcome; reasoning

This is an open access article under the Creative Commons Attribution 4.0 International License 
DOI: https://doi.org/10.24127/ajpm.v9i4.3152

\section{PENDAHULUAN}

Pendidikan diharapkan dapat mempersiapkan peserta didik untuk menguasai berbagai keterampilan abad ke-21 (Zubaidah, 2017). Sejalan dengan ini, menurut (Ayu, 2019) terdapat tiga subjek inti pendidikan abad 21 yaitu 1) life and career skills; 2) learning and innovations skills; 3) information, median and technology skills. Khusus untuk aspek learning and innovation skills (keterampilan belajar dan berinovasi) meliputi: 1) peserta didik mampu mengunakan kemampuan penalaran seperti induktif atau deduktif untuk berbagai situasi; 2) memiliki keterampilan kolaboratif untuk berkolaborasi dengan anggota kelompok lainnya. Konsep learning dan innovation skills dapat dijalankan melalui pembelajaran matematika sehingga para peserta didik akan terbekali dengan penalaran dan kolaboratif dan tentunya akan mampu bersaing di abad ke 21 (Munawwarah, Laili, \& Tohir, 2020).

Namun kenyataan menunjukkan bahwa penalaran peserta didik di Indonesia masih belum menggembirakan berdasarkan hasil literasi PISA dan TIMSS (Rosnawati, 2013). Keterampilan kolaboratif pun belum dapat dimiliki peserta didik secara maksimal karena berdasarkan hasil wawancara terhadap beberapa guru matematika, pembelajaran matematika secara kolaboratif dalam sebuah kelompok memang sering dilakukan namun belum semua peserta didik yang tergabung dalam satu kelompok terlibat secara aktif dan bertanggung jawab karena mereka masih berpikir bahwa dalam bekerja secara kelompok terjadi kompetisi secara individual.

Hal lain yang perlu diperhatikan pada pembelajaran matematika adalah persentase kelulusan nilai UN pada materi statistika dan peluang sebesar $42,37 \%$ pada tingkat sekolah. Persentase ini menunjukkan persentase kelulusan pada materi ini jauh di bawah $50 \%$. Sehingga materi statistik dan peluang menjadi materi yang menarik untuk diangkat dalam suatu penelitian.

Salah satu solusi yang dapat digunakan untuk mengatasi rendahnya penalaran, keterampilan kolaboratif dan hasil belajar peserta didik adalah melalui perbaikan model pembelajaran (Friesen \& Scott, 2013; Zubaidah, 2017). Model-model pembelajaran yang perlu dikembangkan harus dapat diidentifikasi sehingga para peserta didik dapat memiliki keterampilan abad ke-21 khususnya penalaran dan kolaboratif. Salah satu model pembelajaran yang dapat digunakan adalah inquiry dan learning cycle $7 e$. Kedua model pembelajaran ini menekankan pada keaktifan peserta didik untuk dilibatkan dalam kegiatan penyelidikan. Kegiatan penyelidikan diduga dapat mengkonstruk pemahaman peserta didik sehingga dapat meningkatkan hasil belajarnya dan membantu mengasah penalarannya sehingga peserta didik dapat berpikir secara cermat dan logis dalam menghadai tantangan dunia yang semakin kompleks (Farhan, Muhamad; Retnawati, 2014).

Berbagai perbaikan dilakukan para ahli untuk meningkatkan kemampuan penalaran pada model inquiry maupun learning cycle $7 e$ (Anjani, Supeno, \& Subiki, 2020; Farhan, Muhamad; Retnawati, 2014; Fatimah \& Anggrisia, 2019; Hadi, 2016; Widiastuti \& Santosa, 2014; Yuksel, 2019). Begitu pula penelitian tentang hasil belajar pada kedua model ini (Dinnullah, 2018; Kusumaningtyas, 2016; Nurazimah, 2017; Puluhulawa, 
Hulukati, \& Kaku, 2020; Yunita \& Wijayanti, 2018). Selain itu, belum juga ditemukan adanya penelitian tentang keterampilan kolaboratif. Sehingga penelitian ini menawarkan penelitian yang mengukur penalaran, keterampilan kolaboratif dan hasil belajar secara bersamaan melalui analisis data yang kuat dengan hasil yang lebih komprehensif serta tentunya melibatkan sampel penelitian yang berbeda dengan penelitian-penelitian sebelumnya.

Terkait dengan permasalahan di atas, maka tujuan penelitian ini adalah untuk mendeskripsikan keefektifan inquiry dan leraning cycle $7 e$ serta membandingkannya ditinjau dari hasil belajar, kemampuan penalaran dan keterampilan kolaboratif.

\section{METODE PENELITIAN}

\begin{tabular}{lrr}
\multicolumn{2}{c}{ Penelitian $\quad$ ini } & merupakan \\
penelitian & kuantitatif & dengan \\
menggunakan & metode & quasi
\end{tabular} eksperimen. Penelitian eksperimen ini dilakukan dengan menggunakan dua taraf perlakuan (inquiry dan learning cycle 7e) dan tiga respon yaitu hasil belajar, kemampuan penalaran dan keterampilan kolaboratif peserta didik pada matematika. Desain penelitian ini menggunakan pretest-posttest nonequivalent group design.

Subjek penelitian ini adalah seluruh peserta didik kelas VIII se-kota Kupang yang sekolahnya menerapkan kurikulum 2013 dan nilai ujian kenaikkan kelas di atas 70. Sampel penelitian ini adalah peserta didik SMPN 11 kota Kupang kelas VIII A yang berjumlah 31 siswa sebagai kelas eksperimen dan kelas VIII B berjumlah 29 siswa sebagai kelas kontrol. Teknik pengambilan sampel dilakukan dengan random sampling.

Teknik pengumpulan data dalam penelitian ini menggunakan tes dan non tes. Instrumen yang digunakan dalam penelitian ini adalah tes hasil belajar, tes kemampuan penalaran dan non tes (lembar penilaian teman sejawat) keterampilan kolaboratif. Instrumen tes ini ada dua jenis yakni pre-test dan posttest. Pre-test diberikan sebelum diberi perlakuan dengan tujuan untuk mengetahui kondisi awal peserta didik pada kedua kelas. Sedangkan posttest diberikan setelah perlakuan pada kedua kelas. Soal pre-test dan posttest untuk mengukur hasil belajar terdiri atas 20 soal pilihan ganda, sedangkan 5 soal uraian untuk mengukur kemampuan penalaran peserta didik. Soal dibuat berdasarkan kisi-kisi dan indikator yang telah dibuat, memiliki kunci jawaban dan rubrik penskoran. Soal pre-test dan posttest tentu berbeda, namun tetap dengan indikator yang sama.

Instrumen non tes pada penelitian ini adalah lembar penilaian teman sejawat yang terdiri dari 30 butir pernyataan berdasarkan 5 aspek keterampilan kolaboratif. Kriteria penskoran pada instrument ini hanyalah dua yaitu skor 1 untuk pilihan ya dan skor 0 untuk pilihan tidak. Instrumen divalidasi oleh ahli sebelum digunakan.. Selanjutnya, masing-masing instrument dihitung estimasi reliabilitasnya menggunakan rumus Cronbach's Alpha. Suatu konstruk dikatakan reliabel jika nilai Cronbach Alpha $>0,70$. Adapun hasil perhitungan koefisien reliabilitas instrumen penelitian ini ditunjukkan pada Tabel 1.

Hasil estimasi koefisien reliabilitas instrumen tes maupun non tes pada Tabel 1 memiliki nilai Cronbach Alpha melampaui 0,70. Hal ini menunjukan bahwa instrumen yang digunakan pada penelitian ini reliabel sehingga dapat memberikan hasil yang konsisten dalam mengukur hasil belajar, 
DOI: https://doi.org/10.24127/ajpm.v9i4.3152

kemampuan penalaran dan keterampilan kolaboratif peserta didik.

Tabel 1. Hasil estimasi koefisien reliabilitas instrumen tes dan non-tes.

\begin{tabular}{lcc}
\hline Instrumen Penelitian & Pretest & Posttest \\
\hline Tes Hasil Belajar & 0,72 & 0,704 \\
Tes Kemampuan & 0,821 & 0,92 \\
Penalaran & \multicolumn{2}{c}{0,798} \\
Lembar Penilaian & \multicolumn{2}{c}{} \\
Teman Sejawat & \\
\hline
\end{tabular}

Prosedur penelitian ini meliputi 1) membuat instrumen; 2) melakukan validasi instrumen; 3) melakukan uji coba instrumen penelitian; 4) memberikan pretest untuk mengetahui kondisi awal subyek; 5) memberikan perlakuan terhadap kedua kelas; 6) memberikan posttest untuk mengetahui kondisi akhir subyek; 7)menganalisis data hasil pretest dan posttest

Teknik analisis data yang digunakan dalam penelitian ini adalah analisis deskriptif dan analisis inferensial. Analisis deskriptif digunakan untuk menggambarkan kondisi peserta didik terhadap hasil belajar, kemampuan penalaran dan keterampilan kolaboratif baik sebelum diberi perlakuan maupun sesudah diberi perlakuan. Sedangkan analisis inferensial terdiri atas uji keefektifan dan uji perbandingan keefektifan.

Sebelum melakukan uji hipotesis, terlebih dahulu diperlukan uji asumsi manova, uji normalitas (multivariat dan univariat) dan uji homogenitas (multivariat dan univariat) (Stevens, 2009). Uji normalitas multivariat dilakukan dengan menghitung jarak mahalanobis sebelum dan sesudah perlakuan. Pemenuhan uji asumsi normalitas multivariat menggunakan kriteria yaitu sekitar 50\% nilai $d_{i}^{2}<\chi_{0,5(p)}^{2}$ maka dapat dikatakan bahwa data berasal dari populasi yang berdistribusi normal. Sementara itu, uji normalitas univariat menggunakan uji kolmogorov-smirnov.

Uji asumsi selanjutnya adalah homogenitas kedua kelompok yang diuji menggunakan uji Box-M. Kriteria keputusan homogenitas yaitu jika nilai signifikansi yang diperoleh lebih dari 0,05 maka matriks kovarians kedua populasi tersebut homogen. Sedangkan untuk uji homogenitas univariat menggunakan uji Levene's test of equality of error variances menampilkan nilai signifikansi lebih dari 0,05, maka kedua kelompok penelitian homogen secara varians.

Setelah uji asumsi, dilanjutkan dengan menganalisis keefektifan inquiry dan learning cycle $7 e$. Keefektifan pembelajaran yang pada penelitian ini adalah nilai rata-rata hasil belajar, kemampuan penalaran dan keterampilan kolaboratif menggunakan KKM yaitu 70. Uji keefektifan dilakukan secara simultan untuk masing-masing metode pembelajaran menggunakan uji One Sample Hotelling's $T^{2}$.

Kemudian uji Multivariate TwoGroups Test (Hotelling Trance) untuk melihat ada tidaknya perbedaan rerata kedua kelas sebelum dan sesudah diberi perlakuan. Jika pada uji manova sebelum perlakuan tidak ada perbedaan rata-rata antara kedua kelas maka eksperimen dapat di lakukan karena kelas berasal dari kondisi dan situasi yang sama. Selain itu, jika pada uji manova setelah perlakuan terdapat perbedaan maka dilakukan uji independent sample t-test untuk melihat aspek mana yang memberikan perbedaan. 
DOI: https://doi.org/10.24127/ajpm.v9i4.3152

HASIL DAN PEMBAHASAN

Pertama, data yang diperoleh dari hasil penelitian kemudian dianalisis secara deskriptif pada Tabel 2. Dari Tabel 2 dapat dilihat bahwa persentase nilai yang melebihi KKM untuk hasil belajar, penalaran, dan keterampilan kolaboratif sudah melebihi $75 \%$ artinya peningkatannya sangat tinggi.

Tabel 2. Deskripsi data Pretest dan Posttest.

\begin{tabular}{|c|c|c|c|c|c|c|c|}
\hline \multirow[t]{2}{*}{ Deskripsi } & & \multicolumn{2}{|c|}{ Hasil Belajar } & \multicolumn{2}{|c|}{ Penalaran } & \multicolumn{2}{|c|}{$\begin{array}{l}\text { Keterampilan } \\
\text { Kolaboratif }\end{array}$} \\
\hline & & Pretest & Post & Pretest & Post & Pretest & Post \\
\hline Rata-rata & & 13,45 & 80,34 & 11,03 & 76,28 & 46,79 & 51,55 \\
\hline Standar Deviasi & & 8,773 & 11,334 & 7,948 & 14,015 & 8,015 & 6,191 \\
\hline Nilai Tertinggi & & 35 & 95 & 25 & 96 & 60 & 60 \\
\hline Nilai Terendah & & 10 & 55 & 0 & 46 & 32 & 40 \\
\hline Skor Max Teoritik & & 100 & 100 & 100 & 100 & 60 & 60 \\
\hline Skor Min Teoritik & & 0 & 0 & 0 & 0 & 0 & 0 \\
\hline $\begin{array}{l}\text { Persentase Nilai } \\
\text { KKM }\end{array}$ & $\geq$ & $0 \%$ & $93 \%$ & $0 \%$ & $75 \%$ & $65 \%$ & $86 \%$ \\
\hline
\end{tabular}

Selanjutnya hasil uji normalitas dapat dilihat pada Tabel 3 yang menunjukkan hasil uji normalitas untuk pretest dan posttest pada masing-masing kelas telah memenuhi kriteria uji asumsi normalitas yaitu sekitar $50 \%$ nilai $d_{i}^{2}<$ $\chi_{0,5(p)}^{2}$.

Tabel 3. Hasil uji normalitas.

\begin{tabular}{lcc}
\hline $\begin{array}{c}\text { Uji } \\
\text { Normalitas }\end{array}$ & Pretest & Posttest \\
\hline Inquiry & $51,72 \%$ & $60,71 \%$ \\
Learning & $54,83 \%$ & $51,72 \%$ \\
Cycle $7 e$ & & \\
\hline
\end{tabular}

Tabel 4. Hasil uji normalitas univariat.

\begin{tabular}{cccc}
\hline Kelas & $\begin{array}{c}\text { Hasil } \\
\text { Belajar }\end{array}$ & $\begin{array}{c}\text { Kemampuan } \\
\text { Penalaran }\end{array}$ & $\begin{array}{c}\text { Keterampilan } \\
\text { Kolaboratif }\end{array}$ \\
\hline Inquiry & 0,2 & 0,2 & 0,37 \\
Learning & 0,05 & 0,2 & 0,2 \\
Cycle 7e & & & \\
\hline
\end{tabular}

Sementara itu, nilai signifikansi uji asumsi normalitas dapat dilihat pada Tabel 4 yang menunjukkan bahwa asumsi normalitas telah terpenuhi secara univariat karena nilai kolmogorov- smirnov untuk masing-masing aspek lebih dari 0,05.

Uji asumsi berikutnya adalah uji homogenitas kovarians dan varians yang menunjukkan bahwa nilai signifikansi lebih dari 0,05 sehingga data homogen secara kovarians dan secara varians. Hasil uji homogenitas dapat dilihat pada Tabel 5 dan Tabel 6 .

Tabel 5. Hasil uji homogenitas matriks kovarians.

\begin{tabular}{lrc}
\hline Nilai & Pretest & Posttest \\
\hline Box's $M$ & 6,031 & 7,104 \\
$F$ & 0,945 & 1,114 \\
Sig & 0,461 & 0,351 \\
\hline
\end{tabular}

Tabel 6. Hasil uji homogenitas varians.

\begin{tabular}{lc}
\hline \multicolumn{1}{c}{ Aspek } & Sig. \\
\hline Hasil Belajar & 0,357 \\
Kemampuan & 0,904 \\
$\begin{array}{l}\text { Penalaran } \\
\text { Keterampilan }\end{array}$ & \\
Kolaboratif & 0,702 \\
\hline
\end{tabular}

Berdasarkan hasil uji asumsi normalitas dan homogenitas baik secara 
multivariat maupun secara univariat telah terpenuhi, maka pengujian hipotesis dalam penelitian ini dapat dilakukan. Pengujian hipotesis ini menggunakan uji one sample hotelling's $T^{2}$ yang dikenakan pada data posttest untuk kelas inquiry maupun kelas learning cycle 7e. Hasil uji one sample hotelling's $T^{2}$ pada data posttest untuk kelas inquiry maupun kelas learning cycle $7 e$ dapat dilihat pada tabel 7 dengan keputusan menolak $H_{0}$. Sehingga kesimpulan yang diambil adalah pertama, inquiry efektif ditinjau dari hasil belajar, kemampuan penalaran, dan keterampilan kolaboratif. Kedua, learning cycle $7 e$ efektif ditinjau dari hasil belajar, kemampuan penalaran dan keterampilan kolaboratif.

Tabel 7. Hasil Uji One Sample Hotelling's $T^{2}$

\begin{tabular}{lcc}
\hline $\begin{array}{c}\text { Metode } \\
\text { Pembelajaran }\end{array}$ & $\boldsymbol{F}_{\text {hitung }}$ & $\boldsymbol{F}_{\text {tabel }}$ \\
\hline Inquiry & 724,7 & 2,97515 \\
Learning & 284,02 & 2,99124 \\
Cycle 7e & & \\
\hline
\end{tabular}

Uji hipotesis selanjutnya adalah membandingkan metode pembelajaran manakah yang lebih efektif. Sebelum menguji hipotesis ini, terdapat analisis multivariat manova untuk melihat apakah kondisi awal kedua kelas sama atau tidak. Hasil dari perhitungan SPSS ditunjukkan pada tabel 8 yang memberikan keputusan untuk menerima $\mathrm{H}_{0}$ dengan kata lain tidak terdapat perbedaan secara signifikan dari rerata hasil belajar, kemampuan penalaran dan keterampilan kolaboratif pada kelas inquiry dan learning cycle $7 e$ sebelum perlakuan. Artinya kondisi kelas sebelum diberi perlakuan adalah sama.

Melalui analisis yang sama yaitu manova, data yang digunakan adalah data posttest memberikan keputusan untuk menolak $\mathrm{H}_{0}$ dengan kata lain terdapat perbedaan secara signifikan dari rerata hasil belajar, kemampuan penalaran dan keterampilan kolaboratif pada kelas inquiry dan kelas learning cycle $7 e$ setelah perlakuan. Hasil ini dapat dilihat pada tabel 8 .

Tabel 8. Hasil Uji Manova

\begin{tabular}{lcc}
\hline Effect & $\boldsymbol{F}$ & Sig.(1-tailed) \\
\hline $\begin{array}{l}\text { Hotteling's } \\
\text { Pretest }\end{array}$ & 1,481 & 0,230 \\
$\begin{array}{l}\text { Hotteling's } \\
\text { Posttest }\end{array}$ & 3,046 & 0,037 \\
\hline
\end{tabular}

Oleh karena adanya perbedaan dari rerata hasil belajar, kemampuan penalaran dan keterampilan kolaboratif masing-masing setelah diberikan perlakuan sehingga selanjutnya dilakukan uji t-Univariat. Uji tUnivariat yang digunakan adalah uji Independent Samples $t$ Test dengan hasil pada tabel 9. Berdasarkan hasil uji pada tabel 9 diambil sebuah kesimpulan bahwa inquiry tidak lebih efektif atau sama efektifnya dengan learning cycle $7 e$ ditinjau dari hasil belajar dan kemampuan penalaran namun inquiry lebih efektif daripada learning cycle $7 e$ ditinjau dari keterampilan kolaboratif.

Tabel 9. Hasil uji independent samples t test posttest.

\begin{tabular}{cccc}
\hline Aspek & $\boldsymbol{t}$ & Sig.(2-tailed) & Sig.(1-tailed) \\
\hline Hasil Belajar & $-0,575$ & 0,568 & 0,357 \\
Kemampuan Penalaran & $-0,142$ & 0,888 & 0,904 \\
Keterampilan Kolaboratif & 2,729 & 0,009 & 0,702 \\
\hline
\end{tabular}


DOI: https://doi.org/10.24127/ajpm.v9i4.3152

Hasil penelitian menunjukkan bahwa inquiry maupun learning cycle $7 e$ efektif ditinjau dari hasil belajar, kemampuan penalaran dan keterampilan kolaboratif. Tercapainya kriteria keefektifan inquiry pada hasil belajar sesuai dengan hasil penelitian sebelumnya oleh (Abdi, 2014; Aktamiş, Hiğde, \& Özden, 2016) yang menyimpulkan bahwa inquiry efektif ditinjau dari hasil belajar siswa dan kemampuan penalaran. Hal ini sejalan dengan penelitian yang dilakukan oleh (Chen \& She, 2014; Lintuman \& Wijaya, 2020; Rahayu, 2015; Sardin \& Wutsqa, 2015) yang mengemukakan bahwa inquiry efektif ditinjau dari hasil belajar dan penalaran peserta didik. Penelitian ini juga menunjukkan bahwa inquiry efektif ditinjau dari keterampilan kolaboratif karena adanya kegiatan diskusi pada proses pembelajaran.

Kegiatan pembelajaran inquiry diawali dengan tahap orientation dimana peserta didik dirangsang keingintahuannya untuk memahami masalah yang dihadapinya. Kemudian tahapan conseptualitation menuntut peserta didik untuk menyatakan masalah tersebut kedalam sebuah rumusan masalah. Untuk menjawab masalah yang telah dirumuskan perlu adanya tindakan pada tahapan investigation. Tindakan ini dilakukan melalui kegiatan eksperimen atau percobaan. Misalnya peserta didik melakukan eksperimen membung $n$ dadu untuk memahami konsep peluang empirik dan peluang teoritik. Dari hasil eksperimen, para peserta didik memperoleh hasil kemunculan masingmasing mata dadu yang berbeda-beda. Perbedaan inilah yang mengantarkan peserta didik kepada kesimpulan mengenai mengenai peluang empirik. Kesimpulan ini disampaikan oleh masing-masing peserta didik menggunakan bahasanya sendiri sesuai pemahaman mereka. Kemudian saling komunikasi bersama teman sejawat untuk berbagi pemahaman yang mereka miliki. Penelitian ini mendukung teori yang dikemukakan oleh (Artigue, Dillon, Harlen, \& Lena, 2012) bahwa melalui kegiatan penyelidikan membuat dan menyelidiki sebuah konjektur dapat memampukan peserta didik untuk memiliki kemampuan penalaran dan akan sangat berdampak pada hasil belajar dan penalaran peserta didik.

Kriteria keefektifan pun berlaku pada learning cycle 7e. Efektifnya learning cycle $7 e$ ditinjau dari hasil belajar dan penalaran sesuai dengan hasil penelitian sebelumnya (Jack, 2017; Khashan, 2016; Polyiem, Nuangchalem, \& Wongchantra, 2011). Learning cycle $7 e$ juga efektif ditinjau dari keterampilan kolaboratif. Kegiatan pembelajaran learning cycle $7 e$ melalui tahapan elicit, engage, explore, explain, elaborate, evaluate dan extend. Pertama, membangkitkan rasa penasaran peserta didik kemudian mengajukan pertanyaan faktual terkait konsep yang akan diselidiki. untuk menyelidiki permasalahan terlebih dahulu peserta didik bergabung bersama kelompoknya. setelah permasalahan diselidiki, peserta didik diminta untuk memberikan jawaban sesuai pemahamannya. Diakhiri dengan memberikan soal latihan untuk dikerjakan secara individu.

Jika dibandingkan kedua metode ini tidak memberikan perbedaan yang signifikan. Inquiry sama efektifnya dengan learning cycle $7 e$ ditinjau dari hasil belajar dan kemampuan penalaran. Hal ini dikarenakan kedua metode ini menggunakan kegiatan penyelidikan melalui eksperimaen. Namun inquiry lebih efektif daripada learning cycle $7 e$ 
DOI: https://doi.org/10.24127/ajpm.v9i4.3152

jika ditinjau dari keterampilan kolaboratif. Hal ini dikarenakan sebagian besar peserta didik di kelas inquiry memiliki prestasi yang bagus bila dibandingkan dengan kelas learning cycle 7e. Karena belum adanya penelitian mengenai inquiry maupun learning cycle $7 e$ pada keterampilan kolaboratif menjadi keterbatasan dalam mendukung hasil penelitian ini. Akan tetapi, keterbatasan ini memberikan peluang yang besar bagi penelitianpenelitian dimasa yang akan datang mengingat bahwa kolaboratif menjadi salah satu aspek yang harus dimiliki dalam menghadapi abad 21 dan revolusi industry 4.0 (Ghufron, 2018; Zubaidah, 2017).

\section{KESIMPULAN DAN SARAN}

Berdasarkan hasil analisis data dan pembahasan, dapat disimpulkan bahwa inquiry dan learning cycle $7 e$ efektif ditinjau dari hasil belajar, kemampuan penalaran dan, keterampilan kolaboratif dan inquiry sama efektifnya dengan metode learning cycle $7 e$ ditinjau dari hasil belajar dan kemampuan penalaran namun lebih efektif ditinjau dari keterampilan kolaboratif.

Untuk selanjutnya disarankan adanya penelitian yang dapat mengukur penggunaan inquiry maupun learning cycle $7 e$ pada aspek lainnya dalam menyiapkan peserta didik menghadapi abad 21 dan revolusi industry.

\section{DAFTAR PUSTAKA}

Abdi, A. (2014). The Effect of Inquirybased Learning Method on Students' Academic Achievement in Science Course. Universal Journal of Educational Research, 2(1), 37-41. https://doi.org/10.13189/ujer.2014. 020104
Aktamiş, H., Hiğde, E., \& Özden, B. (2016). Effects of the inquirybased learning method on students' achievement, science process skills and attitudes towards science: A meta-analysis science. Journal of Turkish Science Education, 13(4), 248-261. https://doi.org/10.12973/tused.101 $83 \mathrm{a}$

Anjani, F., Supeno, \& Subiki. (2020). Kemampuan Penalaran Ilmiah Siswa SMA dalam Pembelajaran Fisika Menggunakan Model Inkuiri Terbimbing disertai Diagram Berpikir Multidimensi. Lantanida Journal, 8(1).

Artigue, M., Dillon, J., Harlen, W., \& Lena, P. (2012). Learning through Inquiry. In Special section. Retrieved from http://ezproxy.umsl.edu/login?url= http://search.ebscohost.com/login.a spx?direct=true $\& \mathrm{db}=\mathrm{eft} \& \mathrm{AN}=507$ $854414 \&$ site $=$ ehost live $\&$ scope $=$ site

Ayu, P. E. S. (2019). Keterampilan belajar dan berinovasi abad 21 pada era revolusi industri 4.0. Purwadita: Jurnal Agama Dan Budaya, 3(1), 77-83.

Chen, C., \& She, H. (2014). The effectiveness of scientific inquiry with/without integration of scientific reasoning, (September 2013).

Dinnullah, R. N. I. (2018). Perbedaan Model Problem Based Learning dan Discovery Learning Ditinjau Dari Hasil Belajar Matematika Siswa Kelas 4 SD. Scholaria: Jurnal Pendidikan Dan Kebudayaan, 8(2), 132-141. https://doi.org/10.24246/j.js.2018.v 8.i2.p132-141 
DOI: https://doi.org/10.24127/ajpm.v9i4.3152

Farhan, Muhamad; Retnawati, H. (2014). Keefektifan PBL dan IBL Ditinjau dari Prestasi Belajar, Kemampuan Representasi Matematis, dan Motivasi Belajar. Jurnal Riset Pendidikan Matematika, 1(November 2014), 227-240.

https://doi.org/10.21831/jrpm.v1i2. 2678

Fatimah, F. M., \& Anggrisia, N. F. (2019). The Effectiveness of 7E Learning Model to Improve Scientific Literacy. Advances in Social Science, Education and Humanities Research, 277 (Steach 2018), 18-22. https://doi.org/ 10.2991/steach-18.2019.4

Friesen, S., \& Scott, D. (2013). InquiryBased Learning: A Review of the Research Literature, (June).

Ghufron, M. . (2018). Revolusi Industri 4.0: Tantangan, Peluang, Dan Solusi Bagi Dunia Pendidikan. Seminar Nasional Dan Diskusi Panel Multidisiplin Hasil Penelitian Dan Pengabdian Kepada Masyarakat 2018, 1(1), 332-337.

Hadi, W. (2016). Meningkatkan Kemampuan Penalaran Siswa SMP Melalui Pembelajaran Discovery Dengan Pendekatan Saintifik (Studi Kuasi Eksperimen di Salah Satu SMP Jakarta Barat ). Jurnal Pendidikan Matematika, I(1), 93108.

Jack, G. U. (2017). The effect of learning cycle constructivist-based approach on students academic achievement and attitude towards chemistry in secondary schools in north-eastern part of Nigeria. Educational Research and Reviews, 12(7), 456-466. https://doi.org/10.5897/ERR2016.3 095
Khashan, K. (2016). The Effectiveness of Using the 7E' s Learning Cycle Strategy on the Immediate and Delayed Mathematics Achievement and the Longitudinal Impact of Learning among Preparatory Year Students at King Saud University (KSU), 7(36), 40-52.

Kusumaningtyas, W. (2016). Efektivitas Metode Inquiry Terhadap Hasil Belajar Matematika Siswa. EDuMath, 2(1), 102-108.

Lintuman, A., \& Wijaya, A. (2020). Keefektifan model pembelajaran berbasis inkuiri ditinjau dari prestasi belajar dan kepercayaan diri dalam belajar matematika siswa SMP. Jurnal Riset Pendidikan Matematika, 7(1), 1323.

Munawwarah, M., Laili, N., \& Tohir, M. (2020). Keterampilan Berpikir Kritis Mahasiswa Dalam Memecahkan Masalah Matematika Berdasarkan Keterampilan Abad 21. Alifmatika: Jurnal Pendidikan Dan Pembelajaran Matematika, 2(1), 37-58. https://doi.org/ 10.35316/alifmatika.2020.v2i1.3758

Nurazimah. (2017). Pelaksanaan Model Pembelajaran Learning Cycle Untuk Meningkatkan Hasil Belajar Matematika Pada Siswa Sekolah Menengah Pertama. Jurnal Ilmu Pendidikan Sosial, Sains, Dan Humaniora, 3(4), 663-670.

Polyiem, T., Nuangchalem, P., \& Wongchantra, P. (2011). Learning Achievement, Science Process Skills, and Moral Reasoning of Ninth Grade Students Learned by 7e Learning Cycle and Socioscientific Issue-based Learning. Australian Journal of Basic and Applied Sciences, 5(1991-8178), 257-564. 
DOI: https://doi.org/10.24127/ajpm.v9i4.3152

Puluhulawa, I., Hulukati, E., \& Kaku, A. (2020). Pengaruh Model Pembelajaran Learning Cycle dan Penalaran Formal terhadap Hasil Belajar Matematika. Jambura Journal of Mathematics Education, 1(1), 32-40. https://doi.org/10.34312/jmathedu. v1i1.4557

Rahayu, N. (2015). Upaya Meningkatkan Aktivitas Dan Hasil Belajar Matematika Melalui Model Pembelajaran Inkuiri Siswa Kelas VIIB SMP Negeri 3 Sentolo, (3), 5.

Rosnawati, R. (2013). Kemampuan Penalaran Matematika Siswa SMP Indonesia, 1-6.

Sardin, \& Wutsqa, D. U. (2015). Keefektifan Pembelajaran Guided Inquiry Ditinjau Dari Kemampuan Penalaran Siswa SMA Negeri 2 Baubau Kelas XI Semester 2 (pp. 431-442).

Stevens, J. P. (2009). Applied Multivariat statistics for the Social sciences (5^thedition). Madison Ave,NY: Routledge.

Widiastuti, \& Santosa, R. H. (2014). Pengaruh Metode Inkuiri terhadap Ketercapaian Kompetensi Dasar , Rasa Ingin Tahu, dan Kemampuan Penalaran Matematis The Effects of Inquiry Method on the Basic Competency Achievement , Curiosity , and Mathematical Reasoning Skill, 9, 196-204.
Yuksel, I. (2019). The Effects of Research-Inquiry Based Learning on the Scientific Reasoning Skills of Prospective Science Teachers. Journal of Education and Training $\begin{array}{lll}\text { Studies, } & 7(4), & 273 .\end{array}$ https://doi.org/10.11114/jets.v7i4.4 020

Yunita, \& Wijayanti, R. (2018). Pengaruh Penggunaan Model Pembelajaran Learning Cycle 5E terhadap hasil belajar siswa dalam memecahkan masalah matematis berbentuk soal cerita ke guru: Jurnal Ilmu Pendidikan Dasar, 9916(2), 22-28.

Zubaidah, S. (2017). Keterampilan Abad ke-21: Keterampilan Yang Diajarkan Melalui Pembelajaran, (June). Retrieved from https://www.researchgate.net/publi cation/318013627\%0AKETERAM PILAN 